\title{
Government Against Itself: The Leaded Fuel Tax and the $\$ 12,000$ Used Car Tariff
}

\author{
David Pearce
}

\begin{abstract}
0 uch is the scale of government intervention today that regulations often frustrate each other's purpose. An excellent example is provided by the leaded fuel tax and tariffs on car imports, especially the prohibitive tariff on used cars.

In its 1993/94 budget, the Commonwealth government introduced a differential tax on leaded fuel in response to increasing concern about lead in the atmosphere and the effects of lead exposure on children. Effective from February 1994, the tax raised the price of leaded fuel relative to unleaded fuel. John Dawkins, then Treasurer, claimed that this move would 'accelerate the conversion of the motor vehicle fleet to unleaded petrol' (Commonwealth of Australia, 1993:6).

In February 1994, leaded fuel accounted for around 50 per cent of fuel sales. Around 60 per cent of Australia's car fleet was manufactured before 1986, the year in which it became compulsory for new cars to run on unleaded fuel. On the basis of current trends, leaded fuel will not be effectively replaced until 2005 (by then pre1986 cars will probably account for only around 3 per cent of the fleet). This rate of conversion is too slow for some, prompting the differential tax.
\end{abstract}

\section{Effects of the Leaded Fuel Tax}

Although the government did not say so explicitly, the differential tax was presumably aimed at one (or both) of two objectives: to encourage those motorists using pre-1986 cars that can run on unleaded fuel to actually run them on unleaded fuel; or to encourage motorists to buy post-1986 cars. The first of these aims will have a limited impact on the amount of leaded fuel used, while the second cannot be achieved through the use of a leaded fuel tax.

Of the pre-1986 cars currently on the road, only 30 per cent (the most optimistic estimate) are capable of running on unleaded fuel. Thus only a minority of motorists using pre-1986 cars are in a position to modify their behaviour. The leadedfuel tax, with the associated advertising and information campaign, will no doubt influence the behaviour of this minority (the early evidence suggests that it is having some effect). However, owners of pre-1986 cars that cannot run on unleaded fuel must bear the tax with no possibility of altering their behaviour. This is inequitable in that most owners of eight-year-old cars are likely to have relatively low incomes. A cynic could conclude that this policy is a means of raising revenue from those least able to avoid the tax.

Nor will the tax do much to encourage the purchase of post-1986 cars. Since fuel costs are only 14 per cent of the total cost of running a car, the price of fuel is a relatively minor consideration in the decision to replace a motor vehicle. The most 
important factor is the capital cost: the purchase price and the cost of financing it. So a fuel levy will not encourage motorists to replace cars faster than they would otherwise. Estimates from a simple model (CIE, 1994:7) suggest that a 10 per cent reduction in the capital cost of a car would encourage motorists to replace that car two years earlier than otherwise; but that a fuel tax of five cents a litre would have no effect.

\section{Car Prices and Import Protection}

The capital cost of cars is influenced by government policy. In the past, a major determinant of the capital cost of cars has been import protection. Tariffs and quotas raise the price of new cars (and indirectly the price of used cars), so taxing consumers and discouraging them from replacing their aging vehicles. For example, in 1986, when legislation requiring new cars to use unleaded fuel became effective, quotas limited car imports with a tariff of 57.5 per cent within the quota and 100 per cent for any imports above the quota. These arrangements amounted to a tax of $\$ 1.3$ billion on car consumers - a clear disincentive to purchase new cars and one reason why Australia still has a 'problem' with leaded fuel.

True, car tariffs are falling - but not in all cases. In 1992 the government introduced a prohibitive tariff (that is, an effective ban) on imported second-hand motor vehicles. The cars that were going to be imported before the $\$ 12,000$ tariff was introduced had a number of advantages. As well as satisfying the same safety standards as imported new cars, they were between three and five years old, they were around $\$ 4,000$ dollars (30 per cent) cheaper than comparable cars available on the Australian market, and they all ran on unleaded fuel.

Had the import of these cars been allowed they would have provided an efficient and equitable means of accelerating the conversion of Australia's car fleet to unleaded fuel. Effectively banning their import runs directly counter to the objective of using less leaded fuel.

The $\$ 12,000$ car tariff was supposed to prevent disruption to the motor vehicles sectoral plan, under which tariffs were slowly reduced and the industry was restructured. But no reason was given for making it a prohibitive tariff, other than the statement of Senator John Button, then Minister for Industry (quoted in Parliament of the Commonwealth of Australia, 1992:100):

People ask me 'Why $\$ 12,000$ ?'. I say, 'Because we want to knock this thing on the head; that is why $\$ 12,000$ '.

Even at the peak of Australian protectionism, politicians were seldom so clear about the purpose of interfering with free choice. 


\title{
References
}

Centre for International Economics (CIE) (1994), The $\$ 12000$ used car tanif: an impediment to the use of unleaded fuel, Canberra.

Commonwealth of Australia (1993), Budget Speech and Statements I and 2 of Budget Paper No. I 1993-94, AGPS, Canberra.

Parliament of the Commonwealth of Australia (1992), Reports by Senate Standing Committees on Consideration of Bills, AGPS, Canberra.

David Pearce is Principal Policy Analyst with the Centre for International Economics, Canberra.

\section{The Virtue of Cooperation: Australia's Volunteer Fire Brigades}

\author{
Shaun Kenaelly
}

7 The bush fires that erupted in New South Wales in early 1994 reminded many of us that most nural and outer suburban fire-fighting in the country is undertaken by volunteers. There is central coordination, but the ordinary activities of training, fire-prevention and fund-raising belong to the brigades. These are composed entirely of residents, who give freely of their time and labour to these community services. They are the first to respond with their close district knowledge. Only long-standing residents know the directions from which a bushfire is most likely to come; where back-burning might stop it; what sudden turns it may take, whistling through gullies. There is a direct sense of place.

Brigades also respond to house-fires, storm damage, and motor accidents. They are very closely integrated into the life of a township. In the fire-prone Blue Dandenongs outside Melbourne, two brigades sponsor local Carols by Candlelight and have done so for years. Another sends Santa around on the truck to distribute lollies to children. One sponsors an annual art-show; another (with Rotary) a big town fete. That is for fund-raising, of course; another brigade holds a formal dinner-dance. Then there are the weekly street-stalls where ladies from the auxiliary sell cream cakes. One brigade draws up its vehicles outside the fire-station on Anzac Day, as a salute to the RSL parade marching by. On 11 November the siren is sounded to mark beginning and end of the two-minute silence. The composition of the fire brigade would be interchangeable with that of the football team and the roll of honour on the Anzac memorial — and, for that matter, the Surf Lifesaving Club of a coastal town. 